\title{
Keeping it Clean: Pest Control, Roaches and Ants ${ }^{\mathbf{1}}$
}

Mary N. Harrison²

The two most common insects that present pest control problems for Floridians are roaches and ants.

\section{Roaches}

Roaches, also know as waterbugs, croton bugs or palmetto bugs, are very common in Florida. Another common roach found in Florida is the German Roach.

\section{Why you should be concerned about roaches.}

- Roaches destroy food, and damage fabrics, bookbindings, and other materials.

-When roaches come in contact with food, they spread disease and germs.

- Roaches secrete an oily liquid that has a bad odor. This oily liquid can ruin food and soil your belongings.

- Roaches leave a waste, in the form of pellets or an ink-like liquid. Their waste also has a bad odor and soils areas where they live.

\section{How do roaches get in you house?}

- Roaches come into the house by hiding in grocery bags, clothing, and other household goods, or through openings around screens, pipes, or doors.

- Roaches live any place where they find:

- Food,

- Water, and

- A hiding place.

\section{How to prevent roaches from living in your house.}

- Since roaches can hide in folds of paper bags and cardboard boxes, unpack and check supplies before putting them into storage areas.

- Check all food products for signs of roaches. Discard any food that has been in contact with roaches.

1. This document is FCS5232-12, one of a series of the Family Youth and Community Sciences Department, Florida Cooperative Extension Service, Institute of Food and Agricultural Sciences, University of Florida. Original publication date June 2002. Revised November 2005. Visit the EDIS Web Site at http://edis.ifas.ufl.edu.

2. Mary N. Harrison, professor, Department of Family, Youth and Community Sciences, Cooperative Extension Service, Institute of Food and Agricultural Sciences, University of Florida, Gainesville, 32611.

The Institute of Food and Agricultural Sciences (IFAS) is an Equal Opportunity Institution authorized to provide research, educational information and other services only to individuals and institutions that function with non-discrimination with respect to race, creed, color, religion, age, disability, sex, sexual orientation, marital status, national origin, political opinions or affiliations. U.S. Department of Agriculture, Cooperative Extension Service, University of Florida, IFAS, Florida A. \& M. University Cooperative Extension Program, and Boards of County Commissioners Cooperating. Larry Arrington, Dean 
Make your own roach control mixture:

An inexpensive means of controlling roaches is to mix equal parts boric acid (a white powder available at drug stores and grocery stores) with equal parts sugar or flour. Mix these two ingredients together well. Since roaches like starches, the starch or sugar attracts them and the boric acid kills them.

- Put some of this mixture in jar lids in cabinets or places where you have seen the roaches. NOTE: Do not place this mixture where children and pets can get into it. When a roach comes in contact with the boric acid mixture, the mixture sticks to the legs of the roach, eventually killing the roach.

\section{Section Heading}

\section{Ants}

In Florida ants are major pests around the home. They feed on our food and make ugly mounds or anthills in the yard. They crawl over any food they can reach and carry bits of it back to their nests.

Some ants bite and sting.

\section{Controlling Ants}

The same housekeeping strategies for preventing cockroaches also apply to ants. Cleanliness is very important. Foods, especially sweets and those foods with fats, should be stored in tight containers such as metal and glass, but any type of food or food particles can attract and provide food for ants. Proper food storage is very important.

You Need:

- Borax

- Honey or syrup

One difference between ants and cockroaches is that you can often find where ants are coming into the house and treat these pathways. Sprinkling borax in these areas will help keep them out; they dont like to crawl over borax.

\section{Bait Treatments}

Bait treatments are effective for control of many types of ants if they eat the bait. You can purchase baits enclosed in a childproof plastic tray or you can make your own from boric acid.

- 1 level teaspoon boric acid.

- $1 / 2$ cup corn syrup or honey.

- Mix boric acid and honey/syrup.

- Heat until boric acid is dissolved.

- Cool completely. You dont want to burn yourself!

- Mix equal parts water and syrup boric acid mixture.

- Place a small amount of mixture in a lid or use an eyedropper to put a small amount of bait where ants will find it.

- Be sure to keep bait available to ants for 2 weeks.

\section{- Keep bait mixtures out of the reach of children and pets.}

